\title{
Analysis of the Sub-Surface Distribution of Graphite Minerals Using the Geoelectrical Resistivity Method in the Sabilambo Village, Kolaka Regency, Southeast Sulawesi Province
}

\author{
La Hamimu ${ }^{1}$, L.O Ngkoimani ${ }^{2}$, Jahidin ${ }^{1}$, Suryawan $A^{2}$, Usmardin ${ }^{1}$ \\ ${ }^{1}$ Halu Oleo University, Geophysics Engineering Department \\ ${ }^{2}$ Halu Oleo University, Geology Engineering Department
}

*Corresponding author: suryawan_tambang@uho.ac.id

Tel : +6281245806864

Received : Mei 27, 2019; Accepted: Jun 19, 2019.

DOI : 10.25299/jgeet.2019.4.3.2406

\begin{abstract}
Southeast Sulawesi Province is one of the regions in Indonesia that has abundant mineral resources, the availability of several types of minerals is strongly influenced by the diversity of rock formations that make up the area. The metamorphic complex is one of the rock formations in the Southeast Sulawesi Province. Where the rock complex is divided into 2 (two), namely: Pompangeo Complex and Mekongga Complex, the distribution area of this metamorphic rock is estimated around $50 \%$ of the total land area of Southeast Sulawesi Province. This rock complex is very possible to contain mineral deposits, one of which is graphite mineral deposits. However, the problem that is now is the identification of the potential for subsurface distribution of graphite excavated material has not been carried out. Therefore, this research was conducted to determine the potential for subsurface distribution of graphite mineral deposits is using geoelectrical resistivity method where is using Wenner-Schlumberger configuration, this research activity was conducted in the Sabilambo Village in Kolaka Regency, where most of the research area is metamorphic complex. Based on the result of the resistivity analysis, subsurface distribution of graphite mineral deposits in the study area can be found on the surface to a depth of 33.5 meters below ground level, with layer thickness between 1.25 to 27.77 meters and has a resistivity value of $14.9 \Omega \mathrm{m}-86.1 \Omega \mathrm{m}$.
\end{abstract}

Keywords: Graphite, Sub-Surface, Distribution, Geoelectrical Resistivity Method.

\section{Introduction}

South East Sulawesi is one of Province that has resources minerals which is quite an abundance and varied for example laterite nickel contained in Kolaka District, North Konawe District, South Konawe District and Bombana District (Nukdin, 2012), (Tonggiroh et al., 2012), (Kamaruddin et al., 2018), (Irzon and Baharuddin, 2016), besides that there are also deposits of gold minerals in the region Bombana District in associated with Metamorphic Complex (Setiawan et al., 2012), (Idrus et al., 2011), (Surono and A. Tang, 2009), (Fadl in et al., 2016), (Hasria et al., n.d.), (Idrus et al., 2016), (Hasria et al., n.d.). Besides that, heavy metal enrichment is also found in $\mathrm{Mn}, \mathrm{Co}$, and $\mathrm{Cr}$ (Irzon, 2017). The existence of abundant minerals resources in the Southeast Sulawesi Province, one which in influenced by the diversity of rock formations found on the surface, the arrangement of the South East Sulawesi Arm stratigraphy is formed by the meeting of two plates, namely the Indo-Australia Continental Plate and the Pacific Ocean Plate. In general, the stratigraphic arrangement in the Southeast Sulawesi arm consists of microcontinent fragments (low to high-grade schist), ophiolite complexes, and Sulawesi molasses. (Surono, 2010), (Rusmana et al., 1993), (Simandjuntak et al., 1993) (Fig. 1).
The pieces of the Sulawesi Continent are composed of several types of rock formation, including the Complex of Pompangeo and the Complex of Mekongga. The oldest rock of these two rock formation in metamorphic rock which occupies the middle part of the southeast arm of Sulawesi which forms the Mendoke Mountains and the southern part forms the Rumbia Mountains with rock types consisting of schist, quartzite, slate and marble (Surono, 2010), (Rusmana et al., 1993), (Simandjuntak et al., 1993).

Based on geological aspect combined with geographic aspect where the metamorphic rock complex is estimated to have a fairly widespread of about $50 \%$ of the total land area of Southeast Sulawesi Province with include Bombana District, Kolaka District, North Kolaka District, Konawe District, South Konawe District, North Konawe District, and Kendari City (Rusmana et al., 1993), (Simandjuntak et al., 1993). The existence of this vast rock complex has brought valuable mineral deposits, one of which is the potential of graphite mineral deposits.

The presence of graphite minerals is found in the complex area of the Pompangeo and Mekongga Mountain ranges. Where in the alteration zone found in the Mendoke Mountains associated with 
metamorphic rocks there is a carbonization process which is the initial stage of the formation of graphite minerals which are in quartz veins and alteration of mica schist (Hasria et al., 2017).

The research area is in District Kolaka, based on the geological aspect mostly composed of metamorphic rocks from the Mekongga Complex and Pompangeo Complex. (Simandjuntak et al., 1993), (Rusmana et al., 1993) (Fig. 2). Based on the above assumptions, the Kolaka district is one of the regions with the potential for graphite mineral deposits, with a widespread of rocks then it is possible to allow deposits of graphite minerals to be found in such a large distribution.
However, the problems that arise to this day are the identification of the subsurface distribution of graphite mineral deposits that have not been carried out. In this study, we will identify the subsurface distribution of graphite mineral deposits with subsurface geophysical mapping method using geoelectric rock type resistivity. This research as part of the development of Southeast Sulawesi Province as an advanced area of potential aspects of minerals, so that the utilization of minerals can be carried out optimally for the development of future industries that prioritize environmental aspect.

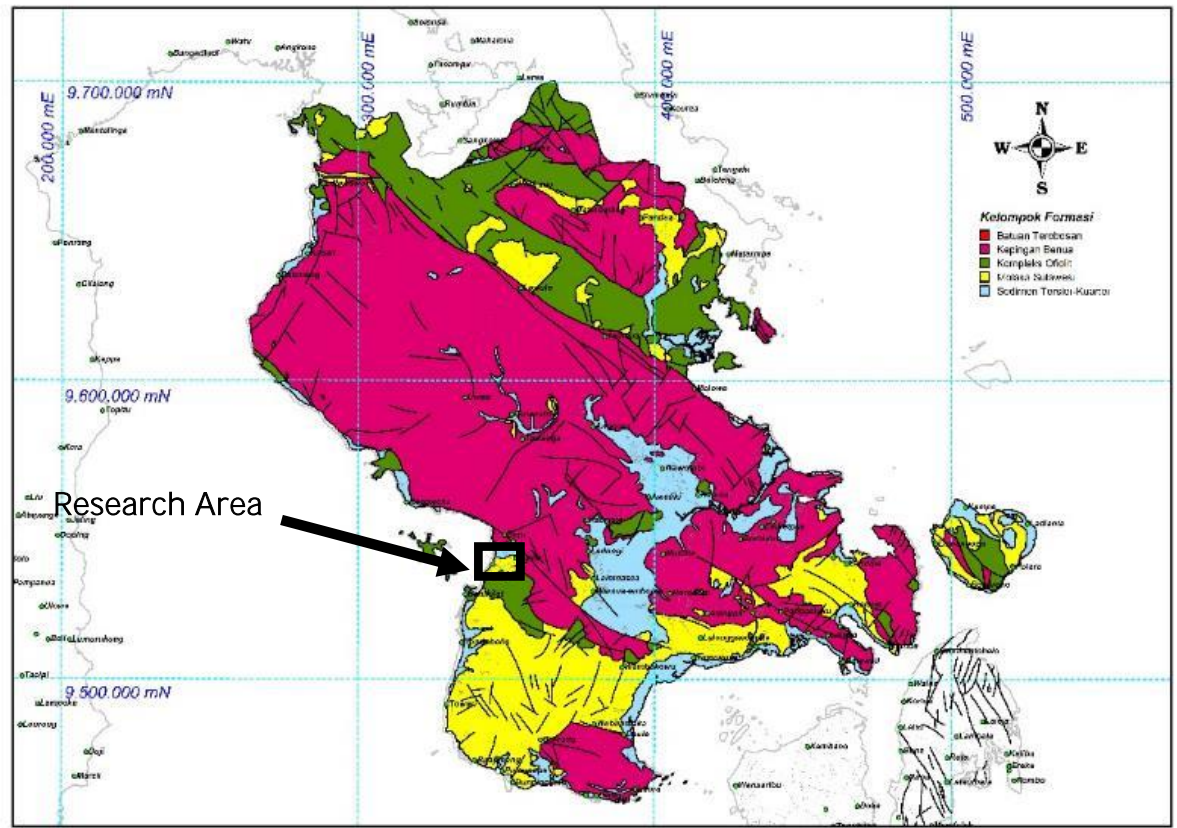

Fig. 1. The geological setting of the southeast arm of Sulawesi which consists of the microcontinent fragment, ophiolite complex, Sulawesi molase and location of the researched area (squared area), in Kolaka Regency, Southeast Sulawesi. (Modified from Surono, 2010, Rusmana et al., 1993 and Simandjuntak et al., 1993).

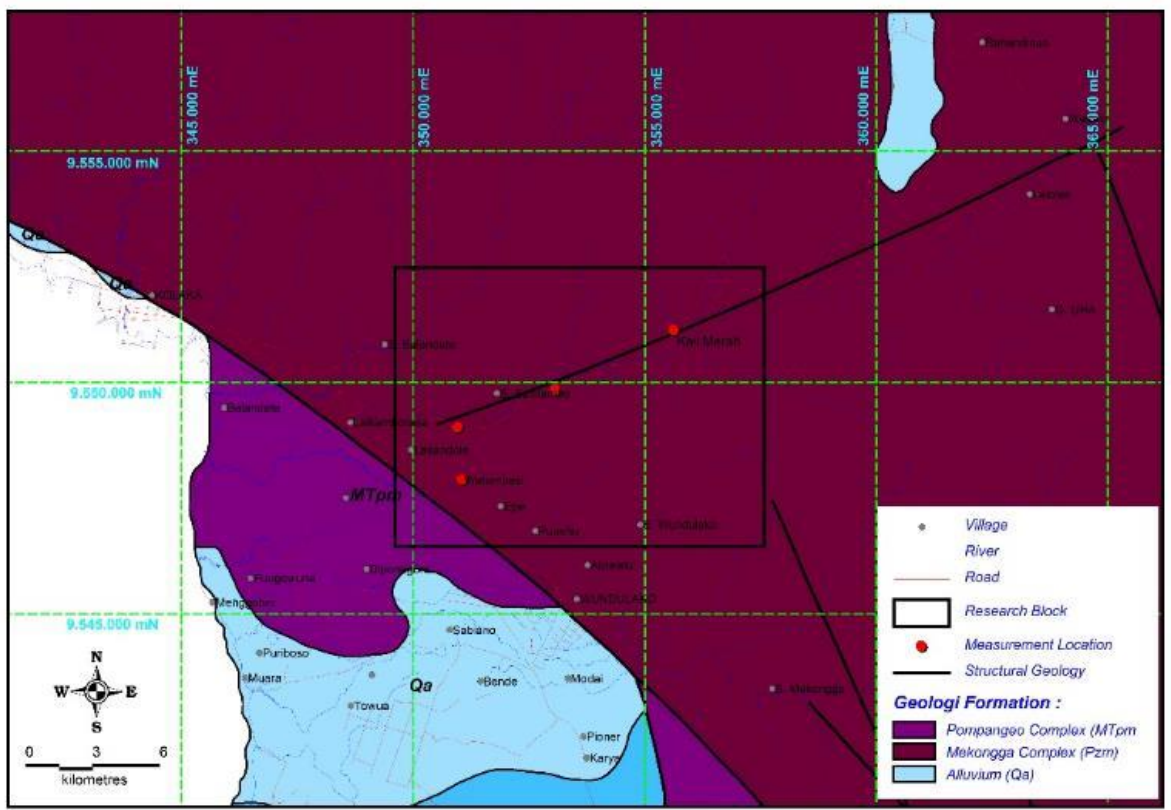

Fig. 2. The regional geological map that shows the position of the Mekongga Complex dan Pompangeo Complex in the Kolaka Regency. (Modified from Simandjuntak et al., 1993, and Rusmana et al., 1993). 


\section{Setting Geology}

\subsection{Geomorphology Research Area}

Southeast Sulawesi Arm consists of 5 (five) morphological units, namely mountain morphology, high hill morphology, low hill morphology, flat morphology, and karst morphology. Mountain morphology units occupy a larger area among all existing morphological units (Surono, 2013).

If the Kolaka Regency is specifically seen, it can be divided into 3 (three) morphological units. The distribution of morphological relief is based on the classification of relief according to Van Zuidam, 1985 (Setyawan et al., 2017). The division of the morphological unit of the study area consists of mountains, hills and plain. (Fig. 4a and 4b)

The mountainous morphology units in the study area are part of the Mekongga mountain range. The highest peak in the Mekongga mountain range is Mount Mekongga which has a height of $2.790 \mathrm{mdpl}$. The mountain range in this unit has a pattern that is almost parallel to the northwest-southeast. This direction is parallel to the pattern of regional fault structures in the region.

This pattern indicates that the formation of mountain morphology is closely related to regional faults. Unit The mountain morphology is formed/ composed by metamorphic rocks and as thick as ophiolite rocks.

Mountain Units formed by metamorphic rocks have a mountain that is cut short by an uneven slope despite sharp angles, whereas mountain units composed of ophiolite rocks have long and straight ridges with relatively flat slopes.

The hilly morphological unit dominates in the southern part especially in Pomalaa Subdistrict, the altitude of the area in this morphological unit reaches $500 \mathrm{Mdpl}$, with the formation of constituent rocks in the form of Ultramafic Complex, Langkowala Formations, and Tokala formations and continental pieces. (Rusmana et al., 1993), (Simandjuntak et al., 1993), and (Surono, 2010). The plain morphology units are generally in the West and dominate the urban areas of Kolaka Regency along the Makassar Strait. This morphological unit is composed of several collections of rock formations, among others: alluvium, ultramafic rock complex, and metamorphic rock complex.

Based on the relief classification according to Van Zuidam, 1985. Where the morphology of the study area consisted of 2 (two) morphological units, namely: hills, and plains. hills morphology unit is a dominant morphological unit found in the study area (Fig. 4c)

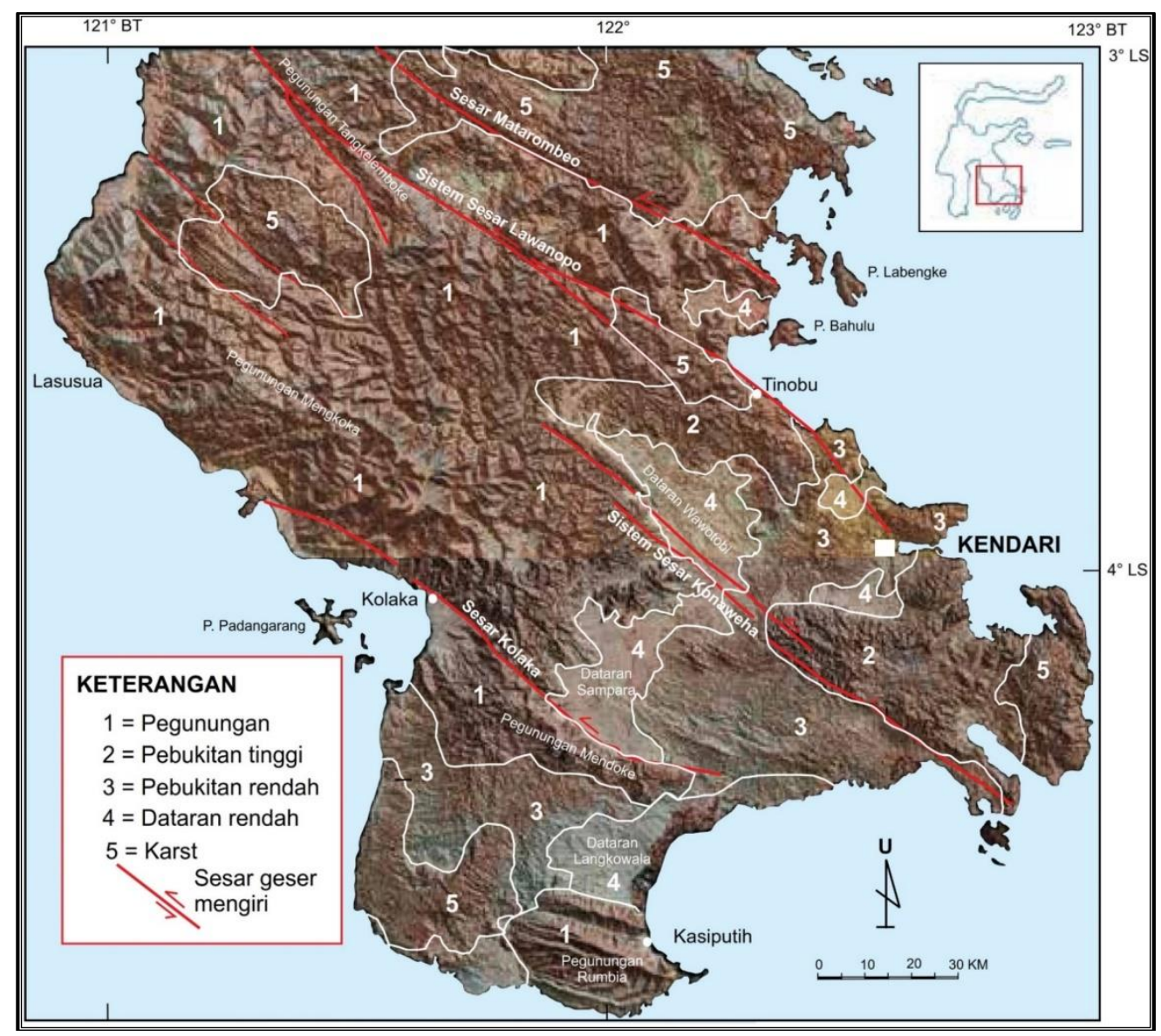

Fig. 3. The morphological form of the Southeast Sulawesi scale 1: 250,000 which is modified based on. (Surono, 2013) 


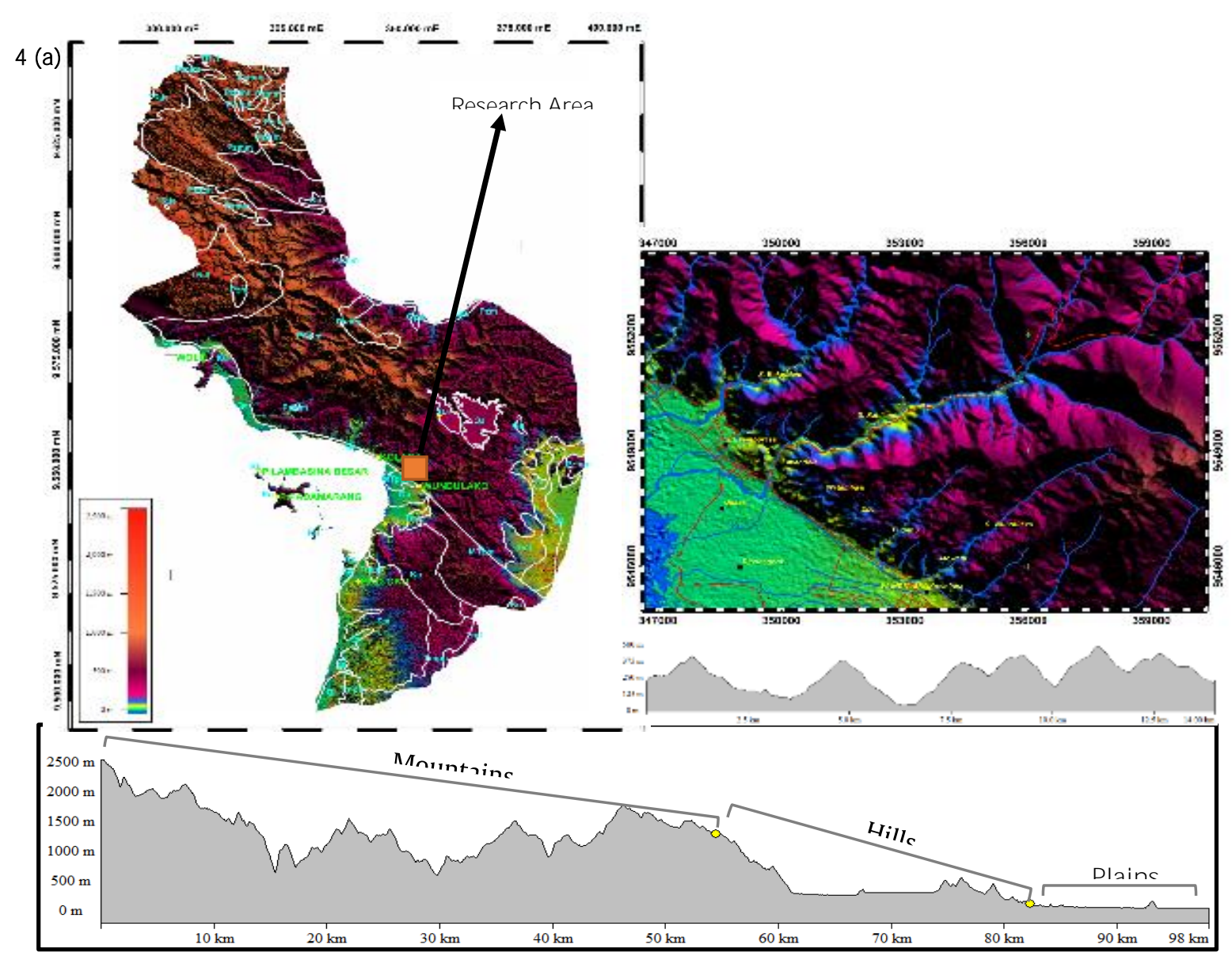

Fig. 4.(a) The morphological form of the Kolaka Regency area is seen using DEM (Digital Elevation Model) which is overlaid on the Geological Map of the Kolaka Sheet (Rusmana et al., 1993), (Simandjuntak et al., 1993) and (Surono, 2010). (b). Vertical cross-section of the morphology of the Kolaka Regency. (c). Morphology unit in the research area.

\subsection{Stratigraphy Research Area}

The rock formations of the Kolaka Regency region are sorted from the youngest which consists of Alluvium (Qa) composed of mud, clay, sand and gravel, the Alangga Formation (Qpa) is composed of conglomerates and sandstones; The Buara Formation (QI) is composed of coral reefs, conglomerates, and sandstones; Langkowala Formation (Tml) is composed of sandstone, shale, and conglomerates; The Pompangeo Complex (MTpm) is composed of various types of schist including mica schist, chlorite schist, graphite mica schist, quartz mists, glaucophane schist, schist Yakut-amphibolite, genes, hornfels, and eclogite.

The Ultramafic Complex $(\mathrm{Ku})$ is composed of harzburgite, dunite, wherlite, serpentinite, gabbro, micro gabbro, basalt, dolerite, rodingites and spot gabbro malih and amphibolite; Tokala Formation (Trjt) is composed of white limestone, marble, and phyllite; and the Mekongga Complex (Pzm) is composed of schist, genes, and quartzite (Rusmana et al., 1993) (Simandjuntak et al., 1993) (Fig. 6)

The research area lithology is dominated by metamorphic rocks with slate rock types. Show the fresh colors of rocks in the form of back, weathered brown color, the texture of lepidoblastic rocks and show the existence of slaty structures. In this slate rock, foliation was also found with the direction of foliation $\mathrm{N} 100^{\circ} \mathrm{E}-355^{\circ} \mathrm{E}$ and the foliation slope between $12^{\circ}-53^{\circ}$. (Fig. 5)

Spread from the new area covers the northern to the western part of the study area, most of these rocks have been disrupted due to the development of the geological structure.

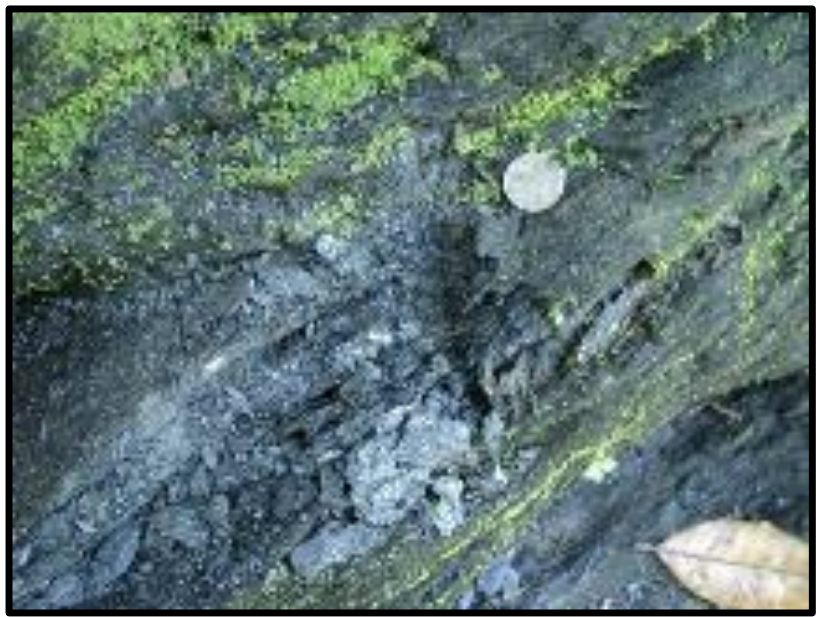

Fig. 5. The lithology of the research area is dominated by the type of slate and is part of the metamorphic Complex Mekongga (MTpm). 


\begin{tabular}{|c|c|c|c|c|}
\hline \multicolumn{2}{|c|}{ GEOLOGICAL AGE } & \multirow{2}{*}{\multicolumn{2}{|c|}{ SYMBOL }} & \multirow{2}{*}{ LITOSTRATIGRAFI } \\
\hline Era & Kala & & & \\
\hline \multirow{2}{*}{$\begin{array}{l}\text { Quarternar } \\
\text { y }\end{array}$} & Holocene & Qa & \multirow{2}{*}{ 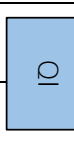 } & \begin{tabular}{l|lr}
$\begin{array}{l}\text { Alluvium: mud, clay, sand, } \\
\text { and gravel. }\end{array}$ & $\begin{array}{l}\text { Buara } \\
\text { coral }\end{array}$ & Formation: \\
reef,
\end{tabular} \\
\hline & Pleistocene & Qpa & & $\begin{array}{lll}\text { Alangga Formation: } & \text { conglomerate dan } \\
\text { Conglomerate, sandstone } & \text { sandstone }\end{array}$ \\
\hline \multirow[t]{2}{*}{ Tertiary } & Miocene & Tml & & $\begin{array}{l}\text { Langkowala Formation: sandstone, shale, and } \\
\text { conglomerate }\end{array}$ \\
\hline & Paleocene & & & \multirow{2}{*}{$\begin{array}{l}\text { Pompangeo Complex: mica schist, chlorite } \\
\text { schist, graphite mica schist, quartz-mica schist, } \\
\text { glaucophane schist, yakut-amphibolite schist, } \\
\text { genes, hornfels, and eclogite. }\end{array}$} \\
\hline \multirow{2}{*}{\multicolumn{2}{|c|}{ Cretaceous }} & MTpm & & \\
\hline & & $\mathrm{Ku}$ & & $\begin{array}{l}\text { Ultramafic complex (Ku): hazburgite, dunite, } \\
\text { wherlite, serpentinite, gabbro, micro gabro, } \\
\text { basal, dolerite, rodingsit, meta gabbro, and } \\
\text { amphibolite }\end{array}$ \\
\hline \multicolumn{2}{|l|}{ Triassic } & TRJt & & $\begin{array}{l}\text { Tokala formation (Trjt): meta limestone, pualam } \\
\text { and phyllite; Mekongga Complex (Pzm) } \\
\text { composed of schist, genes, and quartzite }\end{array}$ \\
\hline \multicolumn{2}{|l|}{ Carbon } & Pzm & & $\begin{array}{l}\text { Mekongga complex (Pzm): schist, genes, and } \\
\text { quartzite. }\end{array}$ \\
\hline
\end{tabular}

Fig. 6. The stratigraphic column of the Kolaka Regency area, (Modification from Rusmana et al., 1993), (Simandjuntak et al., 1993).

\subsection{Structural Research Area}

In the Southeast Sulawesi Arm, the main structure formed after the collision was the shear sliding fault, including the Matarombeo fault, the Lawanopo fault system, the Konawe fault system, the Kolaka fault, as well as many other faults and lines. The geological structure found in the research location is the Kolaka fault, which is formed between Kolaka Subdistrict and Wundulako Subdistrict, Kolaka Regency, besides that in the study area there is also an anticline fold.

\section{Research Method}

Measurement of the subsurface distribution of graphite mineral deposits in the study area was carried out using the resistivity method of the Wenner-Schlumberger configuration. Measurements were made on 4 location, namely the Kali Merah Block, Block KM 12, Blok Sabilambo, and the Lakandole Block. Determination of measurement path location based on the geological conditions of the study area, such as the presence of surface outcrops of graphite mineral deposits. 2D resistivity cross-section model which illustrates the distribution of subsurface graphite mineral deposits obtained through processing data using Res2dinv software.

The potential is determined by using the following Eqn. 1 : (Ngkoimani et al., 2015)

$V=-\int_{0}^{\infty} \frac{\rho_{0} I}{2 \pi r_{0}} d r_{0}=\frac{\rho_{0} I}{2 \pi r_{0}}$
Four electrodes were injected into the soil surface along a straight at pre-determined distances (a) (Fig. 5). The electrical potential of current flow was measured between a pair of inner electrodes (P1 and P2) (Fig. 5) while electrical current flowed was measured between a pair of outer electrodes ( $\mathrm{Cl}$ and C2) (Fig. 7).

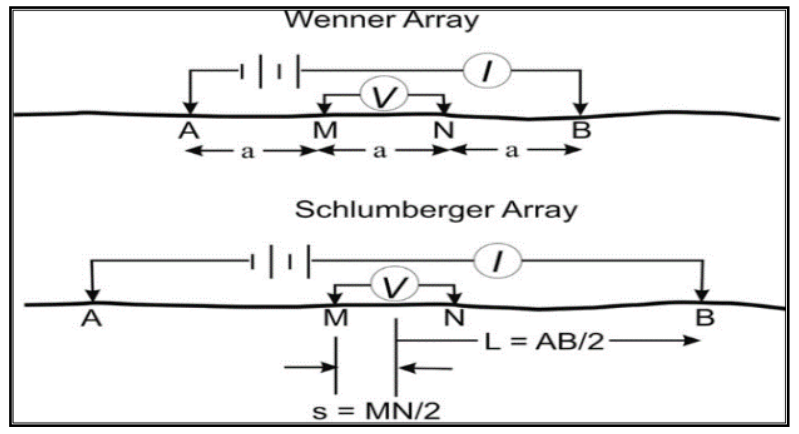

Fig. 7. Schematic of Wenner array and Schlumberger array (Ngkoimani et al., 2015)

The resistivity measurement of Line 1 has 100 meters in length with electrode space about 5 meters. Line 2 has 150 meters in length with electrode space about 5 meters, line 3 has 100 meters in length with electrode space about 5 meters, and line 4 has 200 meters in length with electrode space about 5 meters. (Fig. 8) 

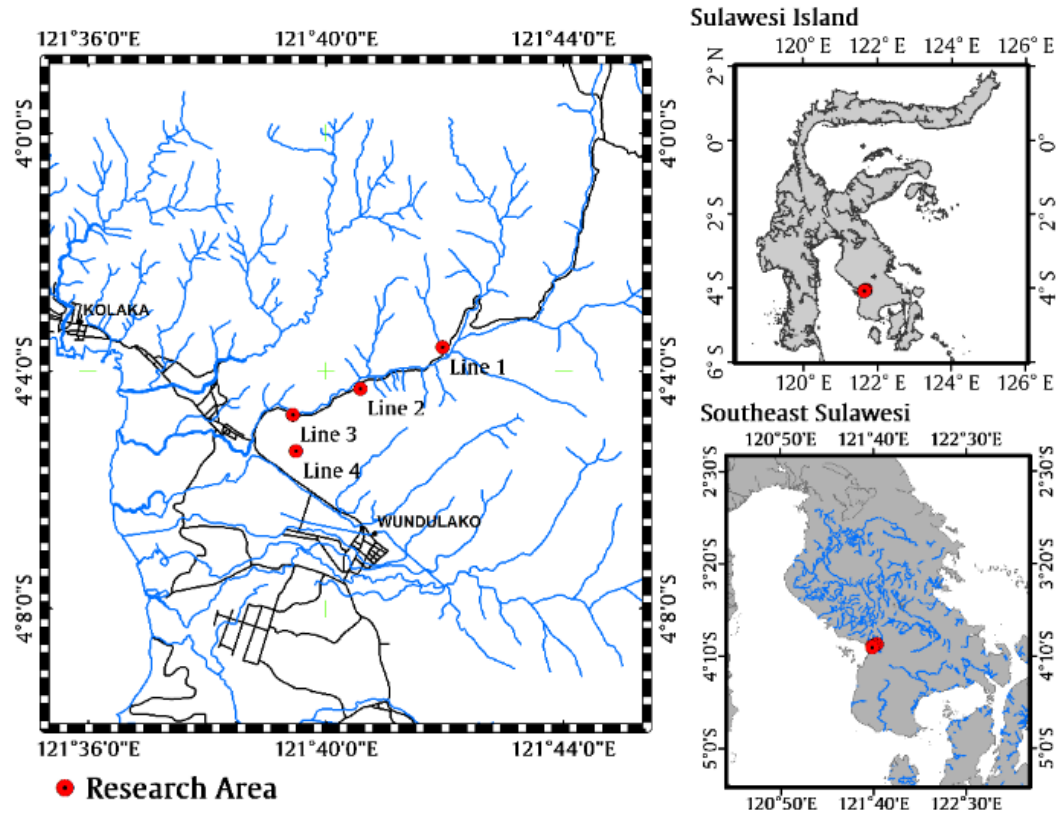

Fig. 8. Map of the location of the research area in Sabilambo Subdistrict, Kolaka Regency, Southeast Sulawesi Province.

\section{Distribution Sub Surface Graphite Minerals}

\subsection{Line $1\left(04^{\circ} 03^{\prime} 36,23^{\prime \prime} S\right.$ and $\left.121^{\circ} 41^{\prime} 58,10^{\prime \prime} \mathrm{E}\right)$}

At Line 1, resistivity measurements are carried out in a $100 \mathrm{~m}$ long track and cut the river. The measurement path passes through the surface outcrop of graphite mineral deposits at the riverbed. The crosssection model of $2 \mathrm{D}$ resistivity of Line 1 is shown in Fig 9.

Based on the resistivity cross-section model in Fig. 9 above, it can be seen that the subsurface resistivity varies which is characterized by colour variation. Variations in resistivity values indicate that subsurface lithology conditions vary. It is suspected that the presence of subsurface graphite mineral deposits is characterized by a blue layer with a resistivity value of 35.1 $\Omega \mathrm{m}-86.1 \Omega \mathrm{m}$.

Estimation of the subsurface distribution of graphite mineral deposits based on the resistivity cross-section model above can be explained as follows:

- Graphite mineral deposits are found at a depth of 0-1.25 meters (electrodeposition 60-65 meters) with a thickness of 1.25 meters. This estimation is strengthened by the outcrop of the graphite mineral layer on the surface of the riverbed.
- Graphite mineral deposits are also found at a depth of 3.8 meters. This layer is spread far to reach a depth of 19.8 meters with a thickness of 16 meters.

\subsection{Line $2\left(04^{\circ} 04^{\prime} 18,07^{\prime \prime} S\right.$ and $\left.121^{\circ} 40^{\prime} 35,23^{\prime \prime} \mathrm{E}\right)$}

At Line 2, resistivity measurements are carried out in a 150 meters track. Around the measurement path, there is a surface outcrop of graphite mineral deposits. The cross-sectional resistivity model of Line 2 is shown in Fig 10.

Based on the resistivity cross-section model in Fig. 10 above, it can be seen that the subsurface resistivity varies which is characterized by colour variation.

Variations in resistivity values indicate that subsurface lithology conditions vary. It is suspected that the presence of subsurface graphite mineral deposits is indicated by a blue layer with a resistivity value of $45.1 \Omega \mathrm{m}-83.7 \Omega \mathrm{m}$.

Estimation of the subsurface distribution of graphite mineral deposits based on the resistivity cross-section model above can be explained as follows:

- Graphite mineral deposits are found at a depth of 6.38 meters to reach a depth of 19.8 meters (thickness of 13.42 meters).

- Graphite mineral deposits are also found at a depth of 12.4 meters to reach a depth of 28.7 meters (thickness of 16.3 meters).

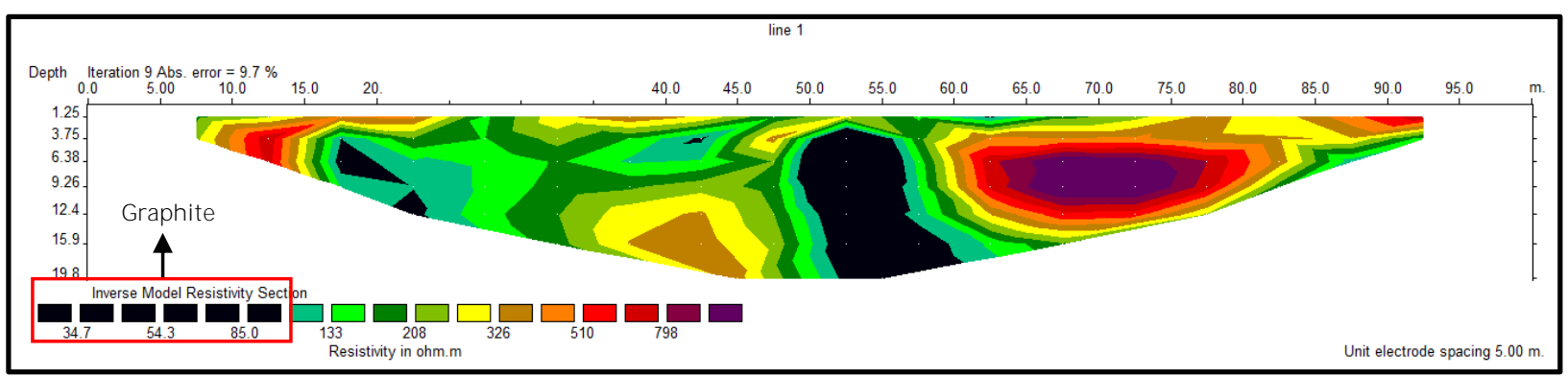

Fig 9. 2D resistivity cross-section model at Line 1. 


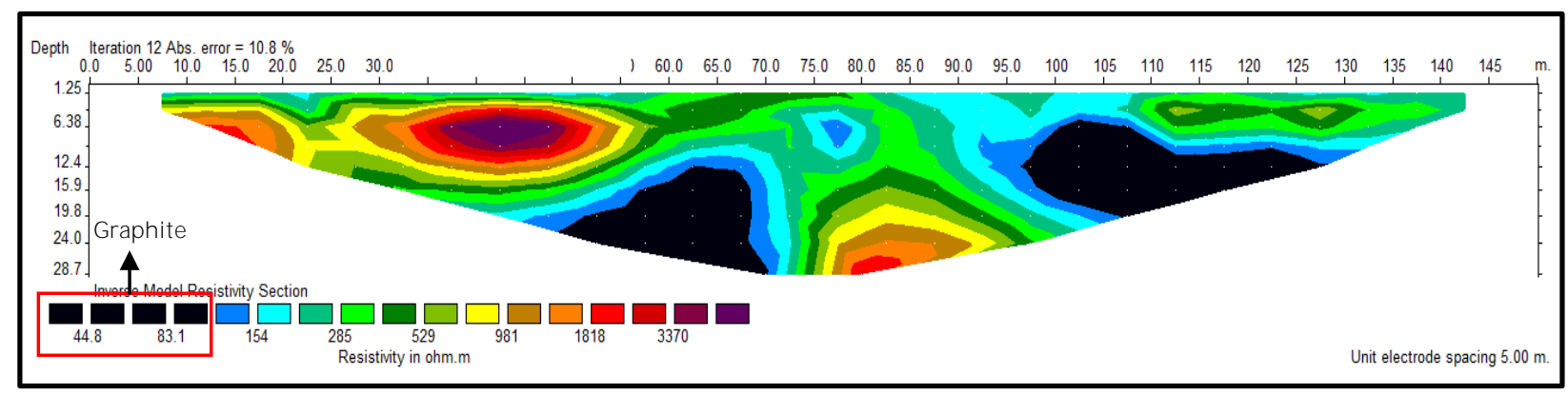

Fig 10. 2D resistivity cross-section model at Line 2.

\subsection{Line $3\left(04^{\circ} 04^{\prime} 44,34^{\prime \prime}\right.$ S and $\left.121^{\circ} 39^{\prime} 26,90^{\prime \prime} \mathrm{E}\right)$}

At Line 3, resistivity measurements are carried out in a 100 meters long track. Around the measurement path, there is a surface outcrop of graphite mineral deposits on the river bank. On this track, measurements are made on the banks of the river in the direction of the river flow. The $2 \mathrm{D}$ resistivity crosssection model of Line 3 is shown in Fig 11.

Based on the resistivity cross-section model in Fig. 11 above, it can be seen that the subsurface resistivity varies which is characterized by colour variation. Variations in resistivity values indicate that subsurface lithology conditions vary. It is suspected that the presence of subsurface graphite mineral deposits is indicated by a blue layer with a resistivity value of $30.9 \Omega \mathrm{m}-85.9 \Omega \mathrm{m}$.

Estimation of the subsurface distribution of graphite mineral deposits based on the resistivity cross-section model above can be explained as follows:
- $\quad$ Graphite mineral deposits are found at a depth of 6.38 meters to reach a depth of 12.4 meters (thickness of 6.02 meters).

- Graphite mineral deposits are also found at a depth of 9.26 meters to reach a depth of 19.8 meters (thickness of 10.54 meters).

\subsection{Line $4\left(04^{\circ} 04^{\prime} 81^{\prime \prime} \mathrm{S}\right.$ and $\left.121^{\circ} 38^{\prime} 90^{\prime \prime}\right)$}

At Line 4, resistivity measurements are carried out in a $\mathbf{2 0 0}$ meters long track. Around the measurement path, there is a surface outcrop of graphite mineral deposits on the edge of the road. On this track, measurements are made on the edge of the highway and parallel to the highway. The $2 \mathrm{D}$ resistivity crosssection model of Line 4 is shown in Fig. 12.

Based on the resistivity cross-section model in Fig. 12 above, it can be seen that the subsurface resistivity varies which is characterized by colour variation.

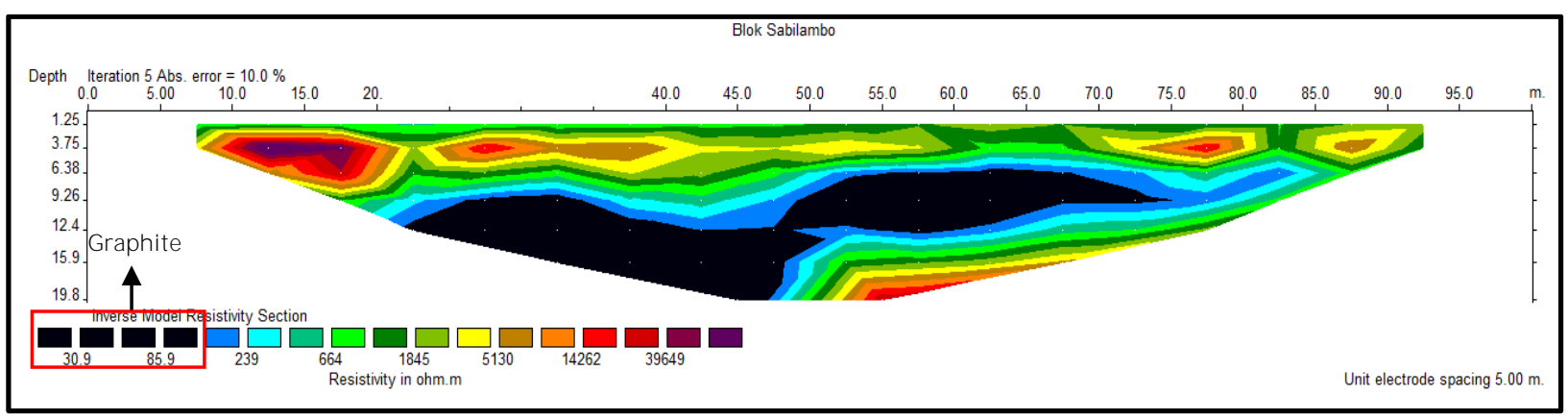

Fig 11. 2D resistivity cross-section model at Line 3.

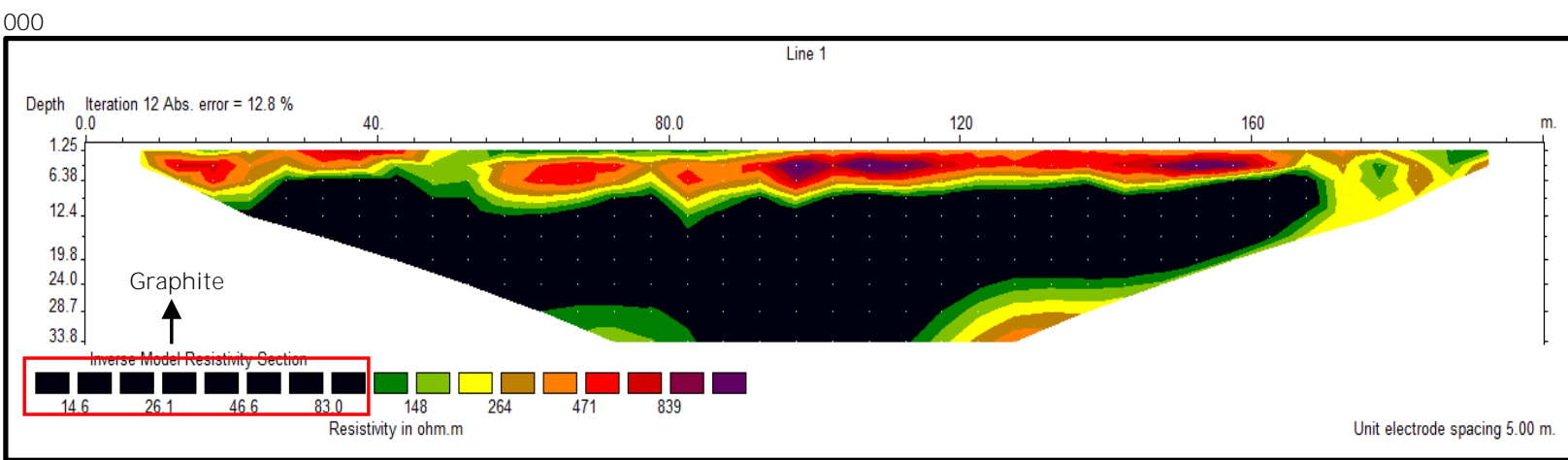

Fig 12. 2D resistivity cross-section model at Line 4 
Variations in resistivity values indicate that subsurface lithology conditions vary. It is suspected that the presence of subsurface graphite mineral deposits is indicated by a blue layer with resistivity values of 14.9 $\Omega \mathrm{m}-83.7 \Omega \mathrm{m}$. Estimating the subsurface distribution of graphite mineral deposits based on the resistivity crosssection model above, it can be explained that the graphite mineral deposit layer is found at a depth of 6.38 meters to reach a depth of 33.15 meters (thickness of 26.77 meters).

\section{Conclusion}

Identification of the subsurface distribution of graphite mineral deposits in Kolaka District, Kolaka Regency was carried out using the WennerSchlumberger (WS) configuration resistivity method. Resistivity measurement was carried out in 4 (four) line measurement, namely the Lin 1, Line 2, Line 3 . And the trajectory of Line 4. Based on resistivity analysis, the subsurface distribution of graphite mineral deposits in the study area can be found on the surface to reach a depth of 33.15 meters with a thickness ranging from 1.25 meters to 26.77 meters and having resistivity values of $14.9 \Omega \mathrm{m}-86,1 \Omega \mathrm{m}$.

\section{Acknowledgements}

We would like to thank the Halu Oleo University for funding support for the implementation of this study with the 2018 Higher Education Internal Basic Research Scheme.

\section{References}

Fadlin, Idrus, A., Warmada, I.W., 2016. Studi Kimia Fisika Fluida Hidrotermal Endapan Emas Orogenik Daerah Wububangka, Kabupaten Bombana, Sulawesi Tenggara. Din. Rekayasa 12, 30-36.

Hasria, Idrus, A., Warmada, I.W., 2017. The Metamorphic Rocks-Hosted Gold Mineralization At Rumbia Mountains Prospect Area In The Southeastern Arm of Sulawesi Island, Indonesia. J. Geosci. Eng. Environ. Technol. 2, 217-223. doi:10.24273/jgeet.2017.2.3.434.

Hasria, Idrus, A., Warmada, I.W., n.d. Preliminary Study Gold Mineralization Hosted By Metamorphic Rocks In The Southeastern Arm Of Sulawesi, Indonesia, in Proceeding The 1st IBSC: Towards The Extended Use Of Basic Science For Enhancing Health, Environment, Energy, And Biotechnology. pp. 375-378.

Idrus, A., Nur, I., Warmada, I.W., Fadlin, 2011. Metamorphic Rock-Hosted Orogenic Gold Deposit Type as a Source of Metamorphic Rock-Hosted Orogenic Gold Deposit Type as a Source of Langkowala Placer Gold, Bombana, Southeast Sulawesi Type Cebakan Emas Orogen pada Batuan Metamorf sebagai Sumber Emas Let. J. Geol. Indonesia. 6, 43-49. doi:10.17014/ijog.6.1.43-49.
Idrus, A., Prihatmoko, S., Harjanto, E., Meyer, F.M., 2016. The Metamorphic Rock-Hosted Gold Mineralization at Bombana ( Southeast Sulawesi ) and Buru Island (Maluku), in Unconventional Exploration Target \& Latest Technique and New Tools in Mineral and Coal Exploration Aston Primera Hotel, Bandung, West Java, 4-6 October 2016. Bandung, Jawa Barat, pp. 1-9.

Irzon, R., 2017. Pengayaan Logam Berat Mn, Co dan Cr pada Laterit Nikel di Kabupaten Konawe Utara, Provinsi Sulawesi Tenggara. Bul. Sumber Daya Geol. 12, 71-86.

Irzon, R., Baharuddin, 2016. Geochemistry of Ophiolite Complex in North Konawe, Southeast Sulawesi. Eksplorium 37, 101-114.

Kamaruddin, H., Ardiansyah IK, R., Rosana, M.F., Sulaksana, N., Titin Y, E., 2018. Profil Endapan Laterit Nikel di Pomalaa, Kabupaten Kolaka, Provinsi Sulawesi Tenggara. Bul. Sumber Daya Geol. 13, 84-105.

Ngkoimani, L. LO, Saleh Isa, L., Jahidin, Syamsurizal, A, S. Makkawaru, A., Asfar, S., 2015. Estimation of Coal Distribution in Tawanga Village, East Kolaka Regency, Southeast Sulawesi by Using DC Resistivity Method. J. Phys. 846, 1-6. doi:10.1088/1742-6596/846/1/012015.

Nukdin, E., 2012. Geologi dan Studi Pengaruh Batuan Dasar Terhadap Deposit Nikel Laterit Daerah Taringgo Kecamatan Pomalaa Kabupaten Kolaka Propinsi Sulawesi Tenggara. J. IIm. MTG 5, 99.

Rusmana, E., Sukido, Sukarna, D., Haryono, E., Simandjuntak, T. 1993. Peta Geologi Lembar Lasusua-Kendari, Sulawesi Skala 1: 250.000

Setiawan, I., Indarto, S., Ismayanto, A., Sudarsono, 2012. Karakter dan Tipe Mineralisasi Hidrotermal di Wilayah Bombana Berdasarkan Studi Mineralogi dan Geokimia. J. Sumber Daya Geol. 22, 155-168.

Setyawan, R., Heryoso, S., Baskoro, R., 2017. Studi Rip Current di Pantai Taman, Kabupaten Pacitan. J. Oseanografi 6, 639649.

Simandjuntak, T., Surono, Sukido, 1993. Peta Geologi Lembar Kolaka Skala, Sulawesi Skala 1: 250.000.

Surono, 2013. Geologi Lengan Tenggara Sulawesi, Edisi II. ed. Badan Geologi.

Surono, 2010. Geologi Lengan Tenggara Sulawesi, in: Publikasi Khusus, Badan Geologi, Kementrian Energi Dan Sumberdaya Mineral. pp. 32-34.

Surono, A. Tang, H., 2009. Kemungkinan Keterdapatan Endapan Emas Primer di Kabupaten Bombana, Sulawesi Tenggara. J. Teknol. Miner. dan Batubara 5, 163-170.

Tonggiroh, A., Suharto, Muhardi, M., 2012. Analisis Pelapukan Serpentin Dan Endapan Nikel Laterit Daerah Pallangga Kabupaten Konawe Selatan Sulawesi Tenggara, in: Prosiding 2012. pp. 978-979.

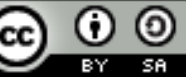
Environment and Technology. All rights reserved. This is an open access article distributed under the terms of the CC BY-SA License (http://creativecommons.org/licenses/by-sa/4.0/). 
